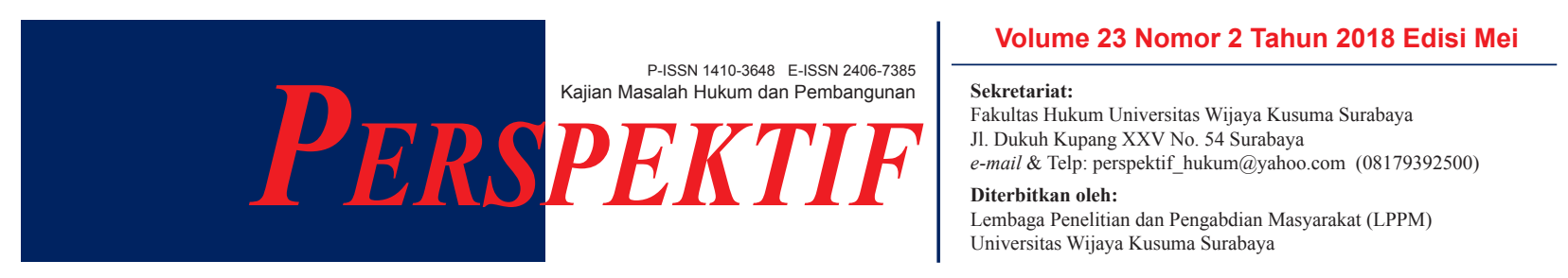

\title{
TANGGUNG JAWAB NOTARIS TERHADAP KESALAHAN DALAM PEMBUATAN AKTA YANG DILAKUKAN OLEH NOTARIS PENGGANTINYA
}

\author{
Putu Adi Purnomo Djingga Wijaya \\ Fakultas Hukum, Universitas Narotama \\ e-mail:putu88purnomo@gmail.com \\ A. A. Andi Prajitno \\ Fakultas Hukum, Universitas Narotama \\ e-mail: andiprajitno@yahoo.com
}

\begin{abstract}
ABSTRAK
Suatu kenyataan bahwa notaris maupun notaris pengganti adalah pejabat umum, yang diberikan kewenangan oleh Undang-Undang untuk membuat akta otentik, sejauh pembuatan akta tersebut tidak dikhususkan bagi pejabat umum lainnya. Dengan adanya persamaan kedudukan hukum antara notaris dengan notaris pengganti tersebut, maka tidak ada keragu-raguan lagi bahwa akta-akta yang dibuat oleh notaris pengganti mempunyai kekuatan hukum yang sama dengan akta-akta notaris, artinya bahwa akta-akta yang dibuat oleh atau dihadapan notaris pengganti bersifat otentik dan mempunyai kekuatan pembuktian yang sempurna sebagaimana dimaksud dalam Pasal 1870 KUHPerdata. Permasalahan timbul saat akta yang dibuat oleh Notaris tersebut terdapat kesalahan. Penelitian ini merupakan penelitian dengan metode normatif. Hasil yang didapatkan adalah Notaris maupun notaris pengganti dapat dituntut ganti rugi bilamana mempunyai kesalahan substantif dalam akta yang dibuatnya, yang tidak sesuai dengan kehendak para pihak akta tersebut merupakan tanggung jawab dari masing-masing pejabatnya. Notaris yang digantikan tidak bertanggung jawab atas kesalahan notaris penggantinya, karena notaris maupun notaris pengganti masing-masing mempunyai hak dan kewajiban masing-masing dalam jabatannya, dan telah disumpah secara pribadi.
\end{abstract}

Kata Kunci: Tanggung Jawab Notaris; Notaris Pengganti

\begin{abstract}
A fact that a notary or a notary substitute is a public official, who is given the authority by law to make an authentic deed, insofar as the deed is not specified for other public officials. With the existence of legal equality between the notary and the substitute notary, there is no doubt that the deeds made by the substitute notary have the same legal force as the notary deeds, meaning that the deeds made by or before the notary substitutes are authentic and have perfect proof power as referred to in Article 1870 of the Civil Code. Problems arise when the deed made by the Notary has an error. This research is a research with normative methods. The results obtained are a Notary or a substitute notary can be sued for compensation when having a substantive error in the deed made, which is not in accordance with the wishes of the parties the deed is the responsibility of each of its officials. The notary who is replaced is not responsible for the error of the successor notary, because the notary and notary substitute each have their respective rights and obligations in their positions, and have been sworn in person.
\end{abstract}

Keywords: Responsibility of The Notary; Substitute Notary 


\section{PENDAHULUAN}

Notaris sebagaimana tertuang dalam Pasal 1 ayat (1) Undang-Undang Jabatan Notaris Nomor 2 Tahun 2014 tentang Sebagian Perubahan Undang-Undang Jabatan Notaris Nomor 30 Tahun 2004 (selanjutnya disingkat UUJN) adalah: "notaris adalah pejabat umum yang berwenang untuk membuat akta autentik dan memiliki kewenangan lainnya sebagaimana dimaksud dalam Undang-Undang ini atau berdasarkan undang-undang lainnya”. Akta Notaris (Notariel Acta) sebagaimana diuraikan ${ }^{1}$ UUJN Pasal 1 ayat (7) adalah: "akta notaris yang selanjutnya disebut akta adalah akta autentik yang dibuat oleh atau dihadapan notaris menurut bentuk dan tata cara yang ditetapkan oleh Undang-Undang ini" dan mempunyai sifat otentik. Sehingga tidak perlu diragukan lagi kesempurnaannya (keabsahannya) karena proses pembuatan maupun kewenangan pejabatnya telah sesuai dengan yang dimaksud pada KUHPerdata Pasal 1868 yaitu: "Suatu akta otentik ialah suatu akta yang di dalam bentuk yang ditentukan undangundang, dibuat oleh atau dihadapan pegawai-pegawai umum yang berkuasa untuk itu di tempat di mana akta dibuatnya". Seperti halnya Akta Hipotek yang dibuat oleh Pejabat Pendaftar dan Pencatan Balik Nama Kapal, jelas bahwa secara hukum, akta otentik yang dibuat oleh Pejabat Pendaftar dan Pencatan Balik Nama Kapal tersebut mempunyai kekuatan hukum yang sempurna, dan tentu saja mempunyai kekuatan pembuktian yang sempurna, karena penggolongan akta otentiknya berdasarkan oleh Undang-Undang dan pejabatnya juga ditunjuk oleh Undang-Undang. ${ }^{2}$

Oleh karena itu, negara memberikan kewenangan kepada notaris untuk membuat alat bukti otentik di bidang hukum keperdataan. Keberadaan notaris sangat penting untuk memenuhi kebutuhan masyarakat yang memerlukan jasa notaris sewaktuwaktu, oleh karena itu kantor notaris tidak boleh kosong dalam jangka waktu lebih dari 7 (tujuh) hari kerja berturut-turut tanpa alasan yang sah sebagaimana tertuang dalam UUJN Pasal 17 ayat (1) huruf b. Bilamana notaris membutuhkan cuti karena alasan tertentu seperti sakit, ada kepentingan keluarga

\footnotetext{
${ }^{1}$ A.A. Andi Prajitno. (2015). Pengetahuan Praktis Tentang Apa dan Siapa Notaris di Indonesia? Sesuai UUJN Nomor 2 Tahun 2014. Surabaya: Perwira Media Nusantara, h. 61.

${ }^{2}$ Fani Martiawan Kumara Putra. (2012). "Surat Kuasa Memasang Hipotek Dalam Jaminan Kapal Laut”. Jurnal Perspektif. 17(2), 98-107.
}

maka sebagaimana tertuang dalam Pasal 11 ayat (1) UUJN yaitu: "notaris yang diangkat menjadi pejabat negara wajib mengambil cuti", dan sebagaimana yang tertuang dalam Pasal 32 ayat (1) UUJN yaitu: "notaris yang menjalankan cuti wajib menyerahkan protokol notaris kepada notaris pengganti".

Hubungan hukum antara notaris dan notaris pengganti baru muncul karena keberadaan notaris pengganti merupakan suatu keniscayaan dan sangat penting dalam rangka mengisi kekosongan pejabat notaris yang sedang cuti, sakit, atau untuk sementara berhalangan menjalankan jabatannya sebagai notaris, agar tetap menjamin kepastian hukum bagi masyarakat. Batas kewenangan notaris, notaris pengganti berbeda. Batas kewenangan notaris pengganti berakhir ketika batas yang tercantum dalam surat keputusannya telah habis. ${ }^{3}$ Setelah masa jabatannya berakhir, notaris melakukan serah terima protokolnya kembali kepada notaris yang digantikannya.

\section{METODE PENELITIAN}

Penelitian yang dilakukan adalah penelitian hukum normatif. Penelitian hukum normatif adalah penelitian hukum yang dilakukan dengan cara mengkaji bahan-bahan yang berasal dari berbagai peraturan perundang-undangan dan bahan lain dari berbagai literatur. Dengan kata lain penelitian ini meneliti bahan pustaka atau data sekunder.

Pendekatan yang dipergunakan dalam penelitian hukum ini adalah pendekatan perundang-undangan (statute approach), pendekatan konseptual (conceptual approach).

\section{PEMBAHASAN}

\section{Tanggung Jawab Notaris Terhadap Kesalahan Dalam Membuat Isi Akta}

Notaris bertanggung jawab merelatir dan mengkonstantir sesuai dengan kehendak para pihak. Dalam membuat perjanjian tidak boleh melanggar aturan dan undang-undang dan notaris tidak boleh memberikan pendapatnya.

Pertanggungjawaban menurut $\mathrm{R}$. Wirjono Prodjodikoro, adalah pertanggungjawaban atas

\footnotetext{
${ }^{3}$ Habib Adjie. (2014). Hukum Notaris Indonesia (Tafsir Tematik Terhadap UU No. 30 Tahun 2004 tentang Jabatan Notaris). Bandung: Refika Aditama, h. 44.
} 
perbuatan seseorang biasanya praktis baru ada apabila orang itu melakukan perbuatan yang tidak diperbolehkan oleh hukum dan sebagian besar dari perbuatan-perbuatan seperti ini merupakan suatu perbuatan yang di dalam KUHPerdata dinamakan dengan perbuatan melanggar hukum (onrechtmatige daad). Onrechtmatige daad atau perbuatan melawan hukum diatur dalam KUHPerdata Buku III Bab III Pasal 1365 sampai dengan Pasal 1380 tentang perikatan-perikatan yang dilahirkan demi undangundang. Adapun bunyi dari Pasal 1365 KUHPerdata adalah sebagai berikut: "tiap perbuatan melanggar hukum yang membawa kerugian kepada seorang lain, mewajibkan orang yang karena salahnya menerbitkan kerugian itu, mengganti kerugian tersebut".

Sedangkan menurut UUJN tanggung jawab notaris tertuang dalam Pasal 16 ayat (12) yaitu: "selain dikenai sanksi sebagaimana dimaksud pada ayat (11), pelanggaran terhadap ketentuan Pasal 16 ayat (1) huruf $j$ dapat menjadi alasan bagi pihak yang menderita kerugian untuk menuntut penggantian biaya, ganti rugi, dan bunga kepada notaris".

Pertanggungjawaban administrasi juga dijelaskan dalam Pasal 85 UUJN, dapat dikenakan sanksi berupa: 1. Teguran lisan; 2. Teguran tertulis; 3 . Pemberhentian sementara; 4. Pemberhentian dengan hormat; 5. Pemberhentian dengan tidak hormat.

\section{Larangan Notaris}

Seorang notaris dalam menjalankan tugasnya dibatasi oleh peratuan perundang-undangan. Pembatasan ini dilakukan agar seorang notaris tidak melanggar aturan dalam menjalankan praktiknya dan bertanggung jawab terhadap segala hal yang dilakukannya. Tanpa adanya pembatasan, seseorang cenderung akan bertindak sewenang-wenang. UUJN juga sudah mengatur bahwa seorang notaris memiliki larangan dan sanksi dalam membetulkan isi akta yang tercantum di dalam Pasal 48 sampai Pasal 50 UUJN Nomor 2 Tahun 2014.

\section{Kesalahan Notaris}

Kesalahan dikategorikan menjadi dua yaitu yang disengaja (dollus) dan lalai (culpa). Kesengajaan adalah perbuatan yang dilakukan dengan diketahui dan dikehendaki. Untuk terjadinya kesengajaan tidak diperlukan adanya maksud untuk menimbulkan kerugian kepada orang lain. Sedangkan kelalaian adalah perbuatan, di mana pembuatnya mengetahui akan kemungkinan terjadinya akibat yang merugikan orang lain.

Kesengajaan (dollus) tidak begitu menimbulkan kesulitan, dan memang sangat jarang sekali notaris sengaja berbuat kesalahan. Seorang notaris yang benar-benar dengan sengaja, dengan direncanakan terlebih dahulu, artinya secara insyaf dan sadar merugikan kliennya, adalah merupakan sesuatu yang sangat jarang terjadi dan apabila terjadi sama dengan bunuh diri. Sepanjang mengenai kesalahan yang sebenarnya (culpa), harus disepakati secara benar bahwa keadaan subjektif dari notaris yang bersangkutan yang menentukan sampai seberapa jauh tanggung jawabnya, akan tetapi harus berdasarkan penilaian objektif.

\section{Upaya Pembetulan dalam Akta Notaris apabila Terdapat Kesalahan Ketik}

Akta relaas atau akta pejabat adalah jenis akta notaris yang berisi tentang uraian secara otentik mengenai suatu tindakan yang dilakukan atau suatu keadaan dilihat atau disaksikan oleh notaris sendiri dalam menjalankan jabatannya. Berbeda dengan akta partai yang harus dibubuhi tanda tangan penghadap agar dapat disebut akta otentik, pada akta relas tidak menjadi permasalahan apakah penghadap menandatangani akta tersebut, asalkan notaris di dalam akta itu menyebutkan sebab penghadap tidak menandatanganinya.

Hal tersebut berarti apabila ada kesalahan ketik dalam suatu akta relas, notaris yang bersangkutan adalah orang yang berwenang memperbaikinya. Bahkan apabila kesalahan ketik tersebut menyangkut hal yang substantif, notaris tetap berwenang untuk membetulkannya karena akta relas adalah akta yang dibuat oleh notaris, bukan dibuat oleh para penghadap di hadapan notaris.

\section{Kesalahan Ditinjau dari UUJN}

Hal ini diatur dalam ketentuan Pasal 51 UUJN, Notaris berwenang melakukan perbaikan kesalahan tulis/ketik terhadap minuta akta dengan cara memanggil para pihak yang di saksikan oleh notaris dan saksi-saksi. Sedangkan Pasal 51 Undang-Undang No. 30 Tahun 2004 notaris yang memperbaiki kesalahan tulis dan para pihak tidak perlu dihadapkan. 
Putu Adi Purnomo Djingga Wijaya dan A.A. Andi Prajitno,

Tanggung Jawab Notaris Terhadap Kesalahan Dalam Pembuatan Akta Yang Dilakukan Oleh Notaris Penggantinya

Untuk mengkualifikasi kesalahan ketik pada minuta akta notaris yang salinannya telah dikeluarkan sebagai perbuatan melanggar hukum, terlebih dahulu harus diuraikan unsur-unsur perbuatan melanggar hukum, yaitu:

1. Adanya suatu perbuatan. Dalam hal ini, notaris melakukan perbuatan, yaitu membuat kesalahan pengetikan dalam akta.

2. Perbuatan tersebut melanggar hukum. Dalam hal ini, notaris melakukan suatu perbuatan yang bertentangan dengan kewajiban hukumnya, yang juga telah diatur secara tegas dalam undangundang yang berlaku, yaitu berkewajiban untuk bertindak saksama, sebagaimana diatur dalam Pasal 16 ayat (1) UUJN.

3. Adanya kesalahan dari pihak pelaku. Dalam melakukan ketik, terdapat kelalaian pada notaris yang bersangkutan, sehingga unsur kesalahan pun terpenuhi.

4. Adanya kerugian bagi korban. Dalam hal adanya kesalahan ketik pada akta notaris yang bersifat substantif, misalnya kesalahan ketik mengenai jumlah uang yang harus dibayar/diterima masingmasing pihak, pihak yang berkepentingan dapat mengalami kerugian secara materiil. Selain itu dapat juga terjadi kerugian immateriil, misalnya perasaan tertekan dan kekhawatiran.

5. Adanya hubungan kausal antara perbuatan dengan kerugian. Kesalahan ketik yang dilakukan oleh notaris, misalnya kesalahan ketik mengenai jumlah uang yang harus dibayar/ diterima masing-masing pihak, secara logis dapat diperkirakan menyebabkan kerugian bagi pihak yang berkepentingan, sehingga dapat dikatakan bahwa ada hubungan kausal antara kesalahan ketik yang dilakukan oleh notaris dengan kerugian pihak yang berkepentingan itu. ${ }^{4}$

\section{Kesalahan Ditinjau dari Hukum Administrasi}

Pasal 85 UUJN berbunyi: "pelanggaran ketentuan sebagaimana dimaksud dalam Pasal 7, Pasal 16 ayat (1) huruf a, b, c, d, e, f, g, h, i, j, dan k, Pasal 17, Pasal 20, Pasal 27, Pasal 32, Pasal 37, Pasal 54, Pasal 58, Pasal 59, dan/atau Pasal 63, dapat dikenai sanksi berupa: a. Teguran lisan; b. Teguran tertulis; c. Pemberhentian sementara; d. Pemberhentian dengan hormat; e. Pemberhentian dengan tidak hormat".

${ }^{4}$ Nelly Juwita, op.cit.
Meskipun pada Pasal 85 UUJN ditentukan 5 (lima) jenis sanksi, tidak semua sanksi dapat diterapkan pada setiap pelanggaran. Dalam hal pelanggaran Pasal 16 ayat (1) huruf a UUJN, pemberhentian dengan hormat merupakan sanksi yang tidak mungkin diterapkan. Dengan demikian, sanksi administratif yang dapat dikenakan atas pelanggaran tersebut adalah sanksi berupa teguran lisan, teguran tertulis, pemberhentian sementara, atau pemberhentian dengan tidak hormat". ${ }^{5}$

\section{Notaris Pengganti}

Menurut UUJN Pasal 1 ayat (3) pengertian notaris pengganti adalah "seorang yang untuk sementara diangkat sebagai notaris untuk menggantikan notaris yang sedang cuti, sakit, atau untuk sementara berhalangan menjalankan jabatannya sebagai notaris".

Adapun syarat untuk menjadi notaris pengganti tercantum dalam Pasal 33 ayat (1) UUJN berbunyi: "syarat untuk dapat diangkat menjadi notaris pengganti dan pejabat sementara notaris adalah warga negara Indonesia yang berijazah sarjana hukum dan telah bekerja sebagai karyawan kantor notaris paling sedikit 2 (dua) tahun berturut-turut", ayat (2) berbunyi: "ketentuan yang berlaku bagi notaris sebagaimana dimaksud dalam Pasal 4, Pasal 15, Pasal 16, dan Pasal 17 berlaku bagi notaris pengganti dan pejabat sementara notaris, kecuali undang-undang ini menentukan lain".

Dalam Pasal 33 ayat (2) UUJN ditegaskan syarat (khusus) untuk dapat ditunjuk sebagai notaris pengganti, notaris pengganti khusus dan pejabat sementara, yaitu: Warga Negara Indonesia; Berijazah Sarjana Hukum; dan Telah bekerja sebagai karyawan kantor notaris paling sedikit 2 (dua) tahun berturutturut. ${ }^{6}$

\section{Prosedur Pengangkatan Notaris Pengganti}

Notaris yang hendak cuti mengajukan permohonan cuti disertai usulan penunjukkan seorang notaris pengganti dan selanjutnya menyerahkan protokol notaris kepada notaris pengganti yang dibuatkan berita acara dan dilaporkan kepada Majelis Pengawas Wilayah. Setelah itu notaris maupun notaris pengganti mengajukan permohonan pelantikan ke

\footnotetext{
${ }^{5}$ Nelly Juwita, ibid.

${ }^{6}$ Habib Adjie. op.cit., h. 106.
} 
Departemen Kementerian Hukum dan Hak Asasi Manusia dengan melampirkan: a. Surat permohonan pelantikan; b. Surat keputusan pengangkatan notaris/ notaris pengganti; c. Berita acara pelantikan.

Dokumen yang dilampirkan untuk pengangkatan notaris pengganti adalah: a. Fotokopi ijazah S1 Sarjana Hukum; b. Fotokopi Kartu Tanda Penduduk (KTP) yang telah dilegalisir oleh notaris; c. Fotokopi akta kelahiran; d. Fotokopi buku nikah (bagi yang sudah menikah); e. Surat berkelakuan baik dari kepolisian; f. Surat keterangan sehat jasmani dan rohani dari dokter pemerintah; g. Pas foto terbaru berukuran $3 \times 4$; h. Daftar riwayat hidup.

\section{Tanggung Jawab Notaris Pengganti}

Dalam Pasal 65 UUJN disebutkan mengenai tanggung jawab notaris pengganti atas akta yang dibuatnya yaitu: "notaris, notaris pengganti, dan pejabat sementara notaris bertanggung jawab atas setiap akta yang dibuatnya meskipun protokol notaris telah diserahkan atau dipindahtangankan kepada pihak penyimpan protokol notaris".

Ruang lingkup tanggung jawab notaris pengganti meliputi 4 (empat) hal yakni: 1. tanggung jawab dalam pelaksanaan jabatan; 2. tanggung jawab secara perdata; 3 . tanggung jawab secara pidana; 4 . tanggung jawab terhadap kode etik.

Tanggung jawab notaris pengganti secara perdata juga ditelusuri dari hubungan hukum dalam suatu perikatan antara notaris pengganti sebagai penyedia jasa dengan klien (para pihak/penghadap) sebagai pengguna jasa, di mana perikatan itu harus memenuhi syarat-syarat sahnya suatu perikatan berdasarkan Pasal 1320 KUHPerdata, baik perikatan antara notaris pengganti dengan kliennya maupun perikatan yang terjadi di antara klien (para pihak) yang akan dikonstatir dalam akta otentik yang dibuat notaris pengganti. Tanggung jawab secara pidana merupakan tanggung jawab pribadi notaris pengganti dalam melaksanakan jabatannya bilamana melakukan suatu perbuatan yang dilarang oleh peraturan perundangundangan dengan ancaman sanksi pidana. Tanggung jawab pidana seorang notaris terkait dengan tanggung jawab terhadap pelaksanaan jabatannya diatur diantaranya dalam Kitab Undang-Undang Hukum Pidana (KUHP), yakni Pasal 52, Pasal 55, Pasal 263, Pasal 264, Pasal 266, Pasal 378 dan Pasal 415 KUHP. Dalam melaksanakan jabatannya seorang notaris pengganti juga harus berpegang teguh kepada kode etik notaris. Keharusan notaris berpegang teguh dengan kode etik notaris diamanatkan dalam Pasal 83 ayat (1) UUJN yang menegaskan bahwa organisasi notaris menetapkan dan menegakkan kode etik notaris. $^{7}$

Tanggung jawab notaris pengganti di dalam pembuatan akta menurut UUJN diatur dalam Pasal 33 ayat (2) yang menegaskan bahwa notaris sebagaimana dimaksud dalam Pasal 15, Pasal 16, dan Pasal 17 berlaku bagi notaris pengganti. Dengan demikian, dapatlah diketahui bahwa dalam hal tanggung jawab notaris pengganti dalam pembuatan akta bila terdapat kesalahan atau kelalaian dapat dikenakan sanksi yaitu yang terdapat dalam Pasal 84 dan Pasal 85 serta dikaitkan dengan Pasal 86 UUJN yang mana menegaskan apabila pihak yang dirugikan pada saat pembuatan akta tersebut dapat menuntut kepada notaris pengganti baik secara perdata, pidana maupun dipandang secara kode etik notaris, sepanjang tidak bertentangan dengan UUJN.

Tanggung jawab notaris pengganti atas akta yang dibuatnya setelah selesai masa jabatan ataupun masih menjabat sebagai notaris pengganti, sepenuhnya berada pada notaris pengganti karena notaris pengganti ialah pejabat yang mandiri. Ketika akan melaksanakan jabatannya, seorang notaris pengganti harus dilantik terlebih dahulu. Meskipun notaris pengganti, bukan berarti yang bersangkutan tidak harus hati-hati, cakap, profesional dalam menjalankan fungsinya sebagai notaris pengganti, yang bersangkutan tetap bertanggung jawab penuh terhadap setiap akta yang dibuat olehnya, maka dari itu seorang notaris pengganti harus memiliki profesionalitas kerja terutama pengetahuan yang luas dan mendalam terhadap pembuatan akta, karena jika terjadi suatu kelalaian akibat olehnya, maka yang bersangkutan harus bertanggung jawab atas akta yang dibuat olehnya.

\section{Tanggung Jawab Notaris yang Digantikan Apabila Terjadi Kesalahan Dalam Pembuatan Akta yang Dilakukan Oleh Notaris Penggantinya}

Berdasarkan Pasal 1866 KUHPerdata dan Pasal 165 HIR akta notaris merupakan alat bukti tulisan

\footnotetext{
${ }^{7}$ Henny Saida Flora. (2012). "Tanggung Jawab Notaris Pengganti Dalam Pembuatan Akta”. Kanun Jurnal Ilmu Hukum. XIV(57), 179-199.
} 
atau surat pembuktian yang utama sehingga dokumen ini merupakan alat bukti persidangan yang memiliki kedudukan yang sangat penting. ${ }^{8}$

Pada dasarnya akta digolongkan ke dalam dua golongan yaitu:

a. Akta di bawah tangan. Akta di bawah tangan adalah akta yang dibuat sendiri oleh pihak-pihak yang berkepentingan tanpa bantuan pejabat umum. Mengenai akta di bawah tangan diatur secara khusus dalam Stb. 1867. Pengertian akta di bawah tangan menurut Pasal 1 Stb 1867 adalah surat-surat daftar (register) catatan mengenai rumah tangga dan surat-surat lainnya tanpa bantuan pejabat. Jadi dapat disimpulkan bahwa akta di bawah tangan diperbuat oleh yang berkepentingan sendiri tanpa campur pejabat umum sesuai dengan isi Pasal 1874 KUHPerdata.

b. Akta otentik. Dalam Pasal 165 HIR/Rbg memuat definisi akta otentik yaitu surat yang dibuat oleh atau dihadapan pegawai umum yang berwenang membuatnya, merupakan bukti yang cukup bagi kedua belah pihak dan ahli warisnya serta sekalian surat itu hanya sekedar pemberitahuan saja, tetapi yang tersebut kemudian itu hanya sekedar diberitahukan yang langsung berhubungan dengan akta itu. ${ }^{9}$

Dari perumusan pasal tersebut dapat diketahui bahwa ada 2 jenis akta otentik yaitu:

a. Akta yang diperbuat oleh (door een) notaris. Jenis akta ini biasanya diberi nama "akta relaas" atau pejabat atau akta "gross verbal" atau "akta berita acara". Yang termasuk jenis akta ini antara lain akta berita acara rapat pemegang saham Perseroan Terbatas, akta pendaftaran atau inventarisasi harta peninggalan, akta berita acara penarikan undian. Akta seperti ini adalah yang dimaksud dan diuraikan oleh Pasal 46 UUJN. Isi dari akta berita acara ini semuanya berupa keterangan atau kesaksian dari notaris yang membuat akta itu tentang apa yang dilihatnya terjadi dihadapan atau disaksikan oleh orang lain, pendek kata apa yang dialaminya.

b. Akta yang diperbuat dihadapannya (ten everstan van een) notaris. Akta ini dinamakan akta pihak-pihak. Isi akta ini adalah catatan notaris

\footnotetext{
${ }^{8}$ Nico. (2003). Tanggungjawab Notaris Selaku Pejabat Umum. Yogyakarta: CDSBL, h. 8.

${ }^{9}$ Henny Saida Flora, op.cit.
}

mengenai keterangan dari para penghadap yang bertindak sebagai pihak-pihak dalam akta yang bersangkutan. ${ }^{10}$

\section{Sumpah Jabatan Notaris}

Dalam janji atau sumpah, mengandung dua hal yang harus dipahami, yaitu: 1. Secara garis lurus bahwa kepada masyarakat dan negara, artinya negara telah memberi kepercayaan kepada kita untuk menjalankan sebagian tugas negara dalam bidang hukum perdata, yakni dalam pembuatan alat bukti yang sah yaitu akta yang memiliki kekuatan bukti yang kuat dan kepada masyarakat yang telah mempercayai bahwa notaris mampu menyatukan kehendaknya ke dalam bentuk akta notaris, dan percaya bahwa notaris mampu menyimpan/ merahasiakan segala keterangan/ucapan yang diberikan dihadapan notaris; 2 . Secara garis lurus bahwa kita wajib bertanggung jawab kepada Tuhan, karena janji atau sumpah yang kita lontarkan berdasarkan agama kita masing-masing, maka dengan demikian yaitu memiliki arti segala sesuatu yang kita kerjakan akan diminta pertanggungjawaban dalam bentuk yang dikehendaki Tuhan. ${ }^{11}$

Dalam Peraturan Pemerintah Republik Indonesia Nomor 11 Tahun 1949 tentang sumpah Jabatan Notaris, Pasal 1 berbunyi: (1) Tiap-tiap Notaris harus bersumpah; (2) Bunyi sumpah itu ialah sebagai berikut: Demi Allah! Saya bersumpah; Bahwa saya, untuk mendapat jabatan saja ini, baik dengan maupun tidak langsung, dengan rupa atau kedok apapun juga, tidak memberi atau menyanggupi akan memberi sesuatu, kepada siapapun juga; Bahwa saja akan setia dan ta'at kepada Negara Republik Indonesia; Bahwa saja akan menghormati para pembesar Kehakiman dan pembesar negara lainnya; Bahwa saja akan menjalankan jabatan saja dengan kejujuran, saksama dan tidak menyebelah; Bahwa saja akan menjalankan peraturan-peraturan yang mengenai jabatan notaris dengan seteliti-telitinya; Bahwa saja akan merahasiakan dengan serapatrapatnya isi akte-akte menurut peraturan-peraturan itu; Bahwa saja dalam menjalankan jabatan saja, saja akan senantiasa menjunjung tinggi hukum dan ingat akan kepentingan masyarakat dan negara.

\footnotetext{
${ }^{10}$ Henny Saida Flora, ibid.

${ }^{11}$ https://notariscimahi.co.id/notaris/sumpah-janji-jabatannotaris, diunduh Selasa tanggal 8 Maret 2018 Pukul 13:20 WIB.
} 
Menurut Andi Prajitno, sumpah jabatan notaris ada 2 (dua) bagian, yaitu: 1. Sumpah jabatan; 2. Rahasia jabatan. ${ }^{12}$

\section{Sumpah Jabatan Notaris Pengganti}

Ketentuan notaris pengganti dapat dibedakan menjadi 2 (dua) bagian, yaitu sebagai berikut:

1. Ketentuan pada saat notaris pengganti masih melaksanakan jabatannya menurut UUJN terdapat dalam Pasal-Pasal sebagai berikut:

a. Pasal 32 ayat (1), ayat (2) dan ayat (3) UUJN. Ketentuan dalam Pasal 32 ayat (1) merupakan kewajiban awal dari notaris pengganti. Di mana dalam Pasal tersebut dinyatakan mengenai kewajiban notaris pengganti untuk menerima protokol dari notaris yang digantikannya. Serah terima protokol dilaksanakan dengan membuat berita acara untuk kemudian berita acara tersebut diserahkan kepada Majelis Pengawas Wilayah. Kemudian dalam Pasal 32 ayat (2) disebutkan mengenai pengembalian kembali protokol dari notaris pengganti kepada notaris yang digantikan setelah notaris yang digantikan tersebut dapat bertugas kembali. Dengan dikembalikannnya protokol tersebut, maka berakhir pula tugas notaris pengganti, namun untuk tanggung jawab atas akta yang pernah dibuatnya pada saat menjabat sebagai notaris pengganti tetap melekat pada notaris pengganti tersebut. ${ }^{13}$

b. Pasal 33 ayat (2) UUJN. Ketentuan notaris pengganti pada Pasal 33 ayat (2) UUJN ini tidak berbeda dengan notaris yang digantikan. Di mana dalam ketentuan pasal ini dinyatakan bahwa ketentuan notaris yang terdapat dalam Pasal 4, Pasal 15, Pasal 16 dan Pasal 17 UUJN juga berlaku untuk notaris pengganti.

2. Ketentuan pada saat notaris pengganti berakhir masa jabatannya dapat dilihat dalam Pasal 32 ayat (2) dan (3), yaitu kewenangan untuk menyerahkan kembali protokol notaris pengganti

${ }^{12}$ Keterangan A.A.Andi Prajitno pada hari Senin tanggal 25 Maret 2018 pukul 10:45 WIB.

${ }^{13}$ Siska Natalia. "Hak Ingkar Notaris Pengganti Setelah Berakhir Masa Jabatannya Pada Proses Peradilan Pidana dan Perdata". Jurnal. Universitas Sriwijaya. kepada notaris yang digantikan, di mana serah terima tersebut dilakukan dengan berita acara untuk kemudian disampaikan kepada Majelis Pengawas Wilayah. Dengan berakhirnya jabatan sebagai notaris pengganti, tidak serta merta berakhir pula tanggung jawab notaris pengganti atas akta yang pernah dibuatnya. Ketentuan umum untuk membuat akta otentik serta ketentuan khusus lainnya yang tercantum dalam Pasal 15, Pasal 16 dan Pasal 17 UUJN memang tidak berlaku lagi untuk notaris pengganti, namun tanggung jawab dan kewajiban atas hasil pekerjaannya selama menjabat sebagai notaris pengganti akan terus melekat pada diri seorang notaris pengganti.

Tanggung jawab dan kewajiban notaris pengganti yang sudah berakhir masa jabatannya tersebut adalah tanggung jawab dan kewajiban untuk menyimpan rahasia jabatannya. Rahasia jabatan yang dimaksud adalah semua keterangan mengenai akta yang pernah dibuatnya termasuk pula isi akta seperti yang tercantum dalam Pasal 4 ayat (2) mengenai sumpah jabatan di mana salah satu isinya menyatakan mengenai sumpah untuk merahasiakan segala keterangan yang diperoleh notaris dalam membuat akta dan Pasal 16 ayat (1) huruf $\mathrm{f}$ mengenai kewajiban untuk merahasiakan isi akta, kecuali undang-undang menentukan lain. Kewajiban ingkar tersebut diberlakukan dengan tujuan untuk menjaga kepentingan dari masyarakat umum yang menggunakan jasa layanan notaris pengganti. ${ }^{14}$

\section{Tanggung Jawab Notaris Pengganti setelah Masa Jabatannya Berakhir Atas Akta yang Pernah Dibuatnya}

Habib Adjie menilai isi Pasal 65 UUJN tersebut sebagai berikut: 1 . Mereka yang diangkat sebagai notaris, notaris pengganti, dan pejabat sementara notaris dianggap sebagai menjalankan tugas pribadi dan seumur hidup sehingga tanpa batas waktu pertanggungjawaban; 2. Pertanggungjawaban notaris, notaris pengganti dan pejabat sementara notaris dianggap melekat kemanapun dan dimanapun mantan notaris, notaris pengganti dan pejabat sementara notaris berada. ${ }^{15}$

\footnotetext{
${ }^{14}$ Siska Natalia, ibid.

${ }^{15}$ Siska Natalia, ibid.
} 
Putu Adi Purnomo Djingga Wijaya dan A.A. Andi Prajitno,

Habib Adjie menilai ada kerancuan mengenai batas pertanggungjawaban notaris pengganti berdasarkan Pasal 65 UUJN di atas, yaitu meskipun semua akta yang dibuat oleh notaris pengganti telah diserahkan atau dipindahkan kepada pihak penyimpan protokol notaris, namun notaris pengganti masih harus bertanggung jawab sampai hembusan nafas terakhir. Sehingga yang logis yaitu jika seorang notaris, notaris pengganti, notaris pengganti khusus, dan pejabat sementara notaris sudah tidak menjabat lagi meskipun yang bersangkutan masih hidup, tidak dapat diminta lagi pertanggungjawabannya dalam bentuk apapun, dan notaris penyimpan protokol wajib memperlihatkan atau memberikan fotokopi dari minuta akta yang diketahui sesusai dengan aslinya oleh notaris penyimpan protokol atau oleh Majelis Pengawas Daerah (MPD) untuk protokol notaris yang telah berumur 25 (dua puluh lima) tahun atau lebih (Pasal 63 ayat (5) UUJN). ${ }^{16}$

Batas pertanggungjawaban notaris, pejabat sementara notaris, notaris pengganti dan notaris pengganti khusus dapat diminta sepanjang mereka masih berwenang dalam melaksanakan tugas jabatan sebagai notaris, atau kesalahan-kesalahan yang dilakukan dalam menjalankan tugas jabatan sebagai notaris dan sanksi-sanksi yang dapat dikenakan terhadap notaris dapat dijatuhkan sepanjang notaris, pejabat sementara notaris, notaris pengganti dan notaris pengganti khusus masih berwenang untuk melaksanakan tugas jabatan sebagai notaris. Dengan konstruksi pertanggungjawaban tersebut di atas, tidak akan ada lagi notaris, notaris pengganti, pejabat sementara notaris atau notaris pengganti khusus diminta pertanggungjawabannya lagi setelah yang bersangkutan berhenti dari tugas jabatannya sebagai notaris. ${ }^{17}$

\section{Tanggung Jawab Notaris Pengganti Atas Kesalahan Dalam Pembuatan Akta}

Tanggung jawab notaris pengganti di dalam pembuatan akta menurut UUJN diatur dalam Pasal 33 ayat (2) yang menegaskan bahwa notaris sebagaimana dimaksud dalam Pasal 15, Pasal 16, dan Pasal 17 berlaku bagi notaris pengganti. Dengan demikian dapatlah diketahui bahwa dalam hal tanggungjawab notaris pengganti dalam pembuatan akta bila terdapat

\footnotetext{
${ }^{16}$ Habib Adjie. op.cit., h. 53

17 ibid.
}

kesalahan atau kelalaian dapat dikenakan sanksi yaitu yang terdapat dalam Pasal 84 dan Pasal 85 serta dikaitkan dengan Pasal 86 UUJN yang mana menegaskan apabila pihak yang dirugikan pada saat pembuatan akta tersebut dapat menuntut kepada notaris pengganti baik secara perdata, pidana maupun dipandang secara kode etik notaris, sepanjang tidak bertentangan dengan UUJN. ${ }^{18}$

Tanggung jawab notaris pengganti dari setiap akta yang dibuatnya adalah sampai meninggal dunia, sebagaimana di dalam Pasal 65 UUJN notaris, notaris pengganti, dan pejabat sementara notaris bertanggung jawab atas setiap akta yang dibuatnya meskipun protokol notaris telah diserahkan atau dipindahkan kepada pihak penyimpan protokol notaris. Dalam praktek ketika akta yang dibuat oleh notaris pengganti tersebut tersangkut kasus hukum, maka notaris penerima protokol akan turut serta memantau dan memberikan saran pendapat dan mendampinginya. Jadi tidak serta merta notaris pengganti dibiarkan begitu saja, tetap mendapat perlindungan dari organisasi notaris. ${ }^{19}$

Mengenai tanggung jawab notaris, notaris pengganti dan pejabat sementara notaris tercantum dalam Pasal 65 UUJN yaitu: "notaris, notaris pengganti, dan pejabat sementara notaris bertanggung jawab atas setiap akta yang dibuatnya meskipun protokol notaris telah diserahkan atau dipindahkan kepada pihak penyimpan protokol notaris". Jadi notaris, notaris pengganti, pejabat sementara notaris itu mempunyai tanggung jawab dalam jabatannya sesuai dengan sumpah jabatan maupun rahasia jabatan yang bersifat pribadi. Bilamana notaris, notaris pengganti, pejabat sementara notaris mendapatkan kesalahan dalam soal akta, maka akta tersebut menjadi di bawah tangan dan bilamana terdapat kerugian material, maka notaris, notaris pengganti, pejabat sementara notaris wajib memberikan ganti rugi.

\section{Bentuk Kesalahan dalam Pembuatan Akta}

Menurut pendapat Andi Prajitno bentuk kesalahan ada 2 (dua) yaitu: 1. Kesalahan pada pengetikan. Berdasarkan ketentuan Pasal 41 UUJN dan Pasal

\footnotetext{
${ }^{18}$ Henny Saida Flora, op.cit.
}

19 Eka Dwi Lasmiatin. (2018). "Tanggungjawab Notaris Pengganti Dalam Hal Notaris Yang Diganti Meninggal Dunia Sebelum Cuti Berakhir". Tesis. Universitas Islam Indonesia. 
1869 KUHPerdata, hal ini membawa pengaruh terhadap akta, salah satunya adalah terhadap kekuatan akta di mana nilai kekuatan akta itu menjadi tidak sempurna, sehingga tidak dapat dijadikan sebagai alat bukti yang kuat dalam proses penyelesaian suatu sengketa, jika suatu saat terjadi perselisihan antara para pihak atau adanya gugatan dari pihak lain. Penulisan akta yang tidak sesuai dengan syarat ketentuan yang diberlakukan oleh undang-undang, hal ini akan masuk dalam kategori suatu pelanggaran, yakni pelanggaran terhadap syarat ketentuan yang diberlakukan undang-undang; 2. Kesalahan pada isi (substansi).$^{20}$ Kesalahan substantif tidak dapat dalam suatu akta tidak akan memberikan sanksi apapun kepada notaris yang membuatnya. Apabila notaris salah dalam merelatir maupun mengkonstantir, maka akibatnya kemungkinan ada yang dirugikan. Bila para pihak menuntut, notaris wajib mengganti kerugian. Bilamana yang melakukan kesalahan adalah notaris pengganti, maka ganti rugi tersebut ditanggung oleh notaris pengganti walaupun dia sudah tidak menjabat lagi. Karena kesalahan notaris pengganti tidak dapat dibebankan kepada notaris yang digantikan.

\section{PENUTUP}

\section{Kesimpulan}

Notaris maupun notaris pengganti dapat dituntut ganti rugi bilamana mempunyai kesalahan substantif dalam akta yang dibuatnya tidak sesuai dengan kehendak para pihak, merupakan tanggung jawab dari masing-masing pejabatnya. Notaris yang digantikan tidak bertanggung jawab atas kesalahan notaris penggantinya karena notaris maupun notaris pengganti masing-masing mempunyai hak dan kewajiban masing-masing dalam jabatannya, telah disumpah secara pribadi, kecuali keberadaan protokol notaris pengganti.

\section{Rekomendasi}

Notaris wajib meningkatkan kwalitas (mengupgrade) dirinya melalui upgrading, sarasehan, seminar, pertemuan-pertemuan berkala. Melakukan tes kelayakan menjalankan jabatan (psikotes) dalam waktu 5 (lima) tahun sekali. Menentukan notaris pengganti sesuai dengan UUJN dan memiliki moral yang baik dan benar. Serah terima protokol harus jelas, benar dan baik saat kepada notaris pengganti maupun pengembalian protokol. Harus ada pemisahan tanggung jawab yang jelas antara notaris dengan notaris pengganti pada saat serah terima protokol meskipun administrasinya dalam 1 (satu) protokol.

\section{DAFTAR PUSTAKA}

\section{Peraturan Perundang-undangan:}

Undang-Undang Nomor 2 Tahun 2017 tentang Jabatan Notaris.

Kitab Undang-Undang Hukum Perdata.

$\mathrm{HIR} / \mathrm{Rbg}$.

\section{Buku:}

A.A. Andi Prajitno. (2015). Pengetahuan Praktis Tentang Apa dan Siapa Notaris di Indonesia? Sesuai UUJN Nomor 2 Tahun 2014. Surabaya: Perwira Media Nusantara.

Habib Adjie. (2014). Hukum Notaris Indonesia (Tafsir Tematik Terhadap UU No. 30 Tahun 2004 tentang Jabatan Notaris). Bandung: Refika Aditama.

Nico. (2003). Tanggungjawab Notaris Selaku Pejabat Umum. Yogyakarta: CDSBL.

\section{Jurnal/Tesis/Website:}

Eka Dwi Lasmiatin. (2018). "Tanggungjawab Notaris Pengganti Dalam Hal Notaris Yang Diganti Meninggal Dunia Sebelum Cuti Berakhir". Tesis. Universitas Islam Indonesia.

Fani Martiawan Kumara Putra. (2012). "Surat Kuasa Memasang Hipotek Dalam Jaminan Kapal Laut". Jurnal Perspektif. 17(2), 98-107.

Henny Saida Flora. (2012). "Tanggung Jawab Notaris Pengganti Dalam Pembuatan Akta". Kanun Jurnal Ilmu Hukum. XIV(57), 179-199.

https://notariscimahi.co.id/notaris/sumpah-janjijabatan-notaris, diunduh Selasa, 8 Maret2018 Pukul 13:20 WIB.

Keterangan A.A. Andi Prajitno pada hari Senin tanggal 25 Maret 2018.

Siska Natalia. "Hak Ingkar Notaris Pengganti Setelah Berakhir Masa Jabatannya Pada Proses Peradilan Pidana dan Perdata". Jurnal. Universitas Sriwijaya.

\footnotetext{
${ }^{20}$ Keterangan A.A. Andi Prajitno pada hari Senin tanggal 25 Maret 2018 Pukul 11:05 WIB.
} 